\title{
Stability of plasma electrolytes in Barricor and PST II tubes under different storage conditions
}

Luis Alfredo Bautista Balbás, Marta Segovia Amaro, Rubén Gómez Rioja*, María José Alcaide Martín, Antonio Buño Soto

Laboratory Medicine, Hospital La Paz, Madrid, Spain

*Corresponding author: rgrioja@salud.madrid.org

\begin{abstract}
Introduction: Sample stability can be influenced by many different factors; evaporation and leakage from residual cells are the most relevant factors for electrolytes. During the analytical phase, samples are usually kept uncapped at room temperature. Once samples are processed, they are usually stored sealed and refrigerated. Long turnaround time and the possibility of "add-on test" need consideration for electrolyte stability. The aim of our study is to examine short-term electrolyte stability in this two-common laboratory working conditions in two different lithium heparin plasma tubes (Barricor and PST II, Becton Dickinson).

Materials and methods: In 39 plasma samples from voluntary subjects we measured sodium $\left(\mathrm{Na}^{+}\right)$, potassium $\left(\mathrm{K}^{+}\right)$and chloride $\left(\mathrm{Cl}^{-}\right)$at 6 time points since centrifugation (0h, 3h, 6h, 9h, 12h and 15h). Maximum allowable bias (clinically significant change) was based in SEQC (Sociedad Española de Química (línica) recommendations; $1 \%$ for $\mathrm{Cl}^{-}, 0.6 \%$ for $\mathrm{Na}^{+}$and $4 \%$ for $\mathrm{K}^{+}$.

Results: In open room temperature tubes, clinically significant changes appeared in $\mathrm{Na}^{+}$and $\mathrm{Cl}^{-}$after 3 hours and in $\mathrm{K}^{+}$after 9 hours in both types of tubes. In refrigerated sealed tubes, all the analytes were clinically stable up to 12 hours in both kinds of plasma tubes. We observed a statistically significant progressive increase in $\mathrm{K}^{+}$levels, which was less pronounced in Barricor tubes.
\end{abstract}

Conclusion: Stability of electrolytes is compromised after 3 hours in open tubes and after 12 hours in sealed tubes.

Key words: specimen handling; potassium; electrolyte

\section{Introduction}

Many factors are known to influence stability. Evaporation is a well-known cause of variation in analyte concentration, especially in automated environments (1), influenced by sample volume, tube type, storage conditions and surface area (2). Storage temperature is also recognized as a significant factor in sample stability, particularly for potassium $\left(\mathrm{K}^{+}\right)$; at low temperatures, the $\mathrm{Na}^{+} / \mathrm{K}^{+}$ATPase is inhibited and $\mathrm{K}^{+}$tends to leave the cells (3).

Plasma samples are used in many emergency laboratories because of the shorter turn-around times when compared to serum. However, it is traditionally acknowledged that serum is more stable for some analytes probably due to the presence of less residual blood cells (4). In serum tubes, gel flows upwards easily and smoothly during centrif- ugation and thus traps cells below. In plasma tubes with gel separator, more residual cells are found in the upper layer affecting stability of electrolytes or glucose.

$\mathrm{BD}^{\circledR}$ Barricor is a new tube designed to obtain stable plasma that contains a barrel-shaped polymer as mechanical separator. During the whole centrifugation time cells flow downwards between the separator and the tube walls, obtaining plasma with less residual cells (5). After centrifugation, the polymer due to its properties, returns to its original shape and is positioned tightly separating plasma from the erythrocytes and the buffy-coat. This is meant to increase plasma stability with respect to gel based tubes. 
The aim of this study was to examine sodium $\left(\mathrm{Na}^{+}\right)$, potassium $\left(\mathrm{K}^{+}\right)$and chloride $\left(\mathrm{Cl}^{-}\right)$stability in $\mathrm{PST}^{\mathrm{TM}}$ II lithium heparin tubes and Barricor lithium heparin tubes in different storage conditions and time periods.

\section{Materials and methods}

This prospective study was conducted over three different days of the same month in the ISO:15189 certified Emergency Laboratory of our tertiary care centre (Hospital Universitario la Paz, Madrid). Analysis was performed in a Siemens Dimension Vista ${ }^{\circledR} 1500$ analyser (Siemens Healthineers, Erlang, Germany) as per manufacturer specifications with an indirect ion selective electrode (V-LYTE ${ }^{\circledR}$ Integrated Multisensor Technology, Siemens Healthineers, Erlang, Germany, REF K800A) for measuring the three ions. Quality control material was run for electrolytes every 12 hours (Liquid Assayed Multiqual, Bio-Rad, Hercules, California), following our quality assurance procedures, and remained in range during the study.

Two storage conditions were chosen as they are the most commonly used in laboratory routine during processing (open and room temperature (rt)) and storage (sealed and refrigerated). Only healthy volunteers participated in this study and they were subdivided in 4 groups, which were not intended to be compared specifically among each other; Barricor open - rt, Barricor sealed - $4{ }^{\circ} \mathrm{C}$, PST II open - rt and PST II sealed $-4^{\circ} \mathrm{C}$.

We defined a priori exclusion criteria consisting of lack of proper consent, current treatment for malignancy, terminal illness or receiving a blood transfusion in the previous month; and posteriori (after sample extraction) exclusion criteria based on serum index (haemolysis, icterus and lipemia), presence of fibrin, inadequate barrier formation and insufficient sample.

In 20 healthy volunteers, we collected blood in 5.5 $\mathrm{mL}$ BD Barricor ${ }^{\mathrm{TM}}$ tubes (Vacutainer ${ }^{\circledast}$, Becton Dickinson, Plymouth, UK; REF 365039). In 22 different volunteers, we collected blood in a lithium heparin LH PST $^{\mathrm{TM}}$ /I $3 \mathrm{~mL}$ tube (Vacutainer ${ }^{\circledR}$, Becton Dickinson Plymouth, UK; REF 367374). All the partici- pants were adults randomly chosen from our clinical chemistry department and gave appropriate informed consent. All the samples were obtained in our centre early in the morning (between 8 and $9 \mathrm{am}$ ) and centrifuged upon arrival at our emergency laboratory (no longer than 30 minutes after collection) for 10 minutes at $3000 \mathrm{~g}$. We excluded two Barricor samples and one PST tube due to insufficient sample. Table 1 shows groups characteristics.

Duplicate electrolytes measurements were carried out in the samples almost immediately after centrifugation (0 hours) and after 3, 6, 9, 12 and 15 hours. Between this time points half of the tubes of each type (PST II and Barricor) were stored open and at room temperature $\left(23-27{ }^{\circ} \mathrm{C}\right.$ controlled temperature) and the other half were sealed with Parafilm ${ }^{\circledast}$ and refrigerated $\left(4-6^{\circ} \mathrm{C}\right.$ controlled temperature).

The average of each pair of duplicate measurements was calculated and used in statistical analysis. For each group, a paired two-tailed t-test was performed using the values at $0 \mathrm{~h}$ as initial paired values $\left(C_{0}\right)$ versus the values $\left(C_{t}\right)$ at different time points $(3,6,9,12$ and 15 hours), using software $R v$ 3.3.1. Statistically significant change was considered to occur when $P$ value was less than 0.05 .

We also calculated the bias $\left(\left(C_{t}-C_{0}\right) / C_{0} \times 100\right)$ with respect to the average initial value $\left(C_{0}\right)$ for each group and calculated the confidence intervals $(\mathrm{Cl})$ for small samples (calculated with the standard mean error and the two-tailed T-distribution with $a=0.05$ ). We used SPSS v. 20 (IBM Corp., Armonk, USA) in this case.

There are several specifications of clinical significance to be used in stability studies $(3,4)$. We followed the Spanish Society for Clinical Chemistry (Sociedad Española de Química Clínica, SEQC) criteria of maximum allowable bias (MAB) obtained from reference change value formula based on the principle that the same sample has no biological variation: $M A B=1.65 \times C V_{a}$, where $C V_{a}$ is the analytical coefficient of variation which should be half the known $\mathrm{CV}_{\mathrm{i}}$ (intraindividual biological coefficient of variation) or less (6). In laboratories where the $\mathrm{CV}_{\mathrm{a}}$ approximates the desirable one (this is our 
situation) the tabulated MAB limits are $\mathrm{Na}^{+}: 0.6 \%$, $\mathrm{K}^{+}: 4.0 \%$ and $\mathrm{Cl}^{-}: 1.0 \%$. Clinically significant deterioration was considered to happen in each group and time when the $95 \% \mathrm{Cl}$ lied completely outside these specifications.

We also calculated the analytical CVa of each group, defined as the average of all the coefficients of variation between pairs of duplicate measurements and compared it to the CVa obtained from our internal quality control in the three previous months ( $\left.\mathrm{Na}^{+}: 0.45 \%, \mathrm{~K}^{+}: 2.0 \%, \mathrm{Cl}^{-}: 0.7 \%\right)$.

\section{Results}

All the analytical CVa (Table 1) were smaller than the laboratory $\mathrm{CVa}$, $\left(\mathrm{Na}^{+} 0.2 \%\right.$ vs. $0.45 \%, \mathrm{~K}^{+} 0.20 \%$ vs. $2 \%, \mathrm{Cl}^{-} 0.25 \%$ vs. $0.7 \%$, and similar between groups (different analytical series).

Figure 1 and Table 2 show the average bias (\%) and Cls for the results of different time points, analytes and group. In open tubes kept at room temperature all the analytes exhibited statistically significant differences since the first study time ( 3 hours) both for Barricor and PST II tubes. The main deterioration effect in these tubes is evaporation, which causes approximately a $0.5-1 \%$ increase per hour, similar across all the electrolytes.

These changes were clinically significant at 3 hours in $\mathrm{Na}^{+}$and $\mathrm{Cl}^{-}$(MABs of $0.6 \%$ and $1 \%$, respectively) and at $9 \mathrm{~h}$ in $\mathrm{K}^{+}$(MAB of $\left.4 \%\right)$.

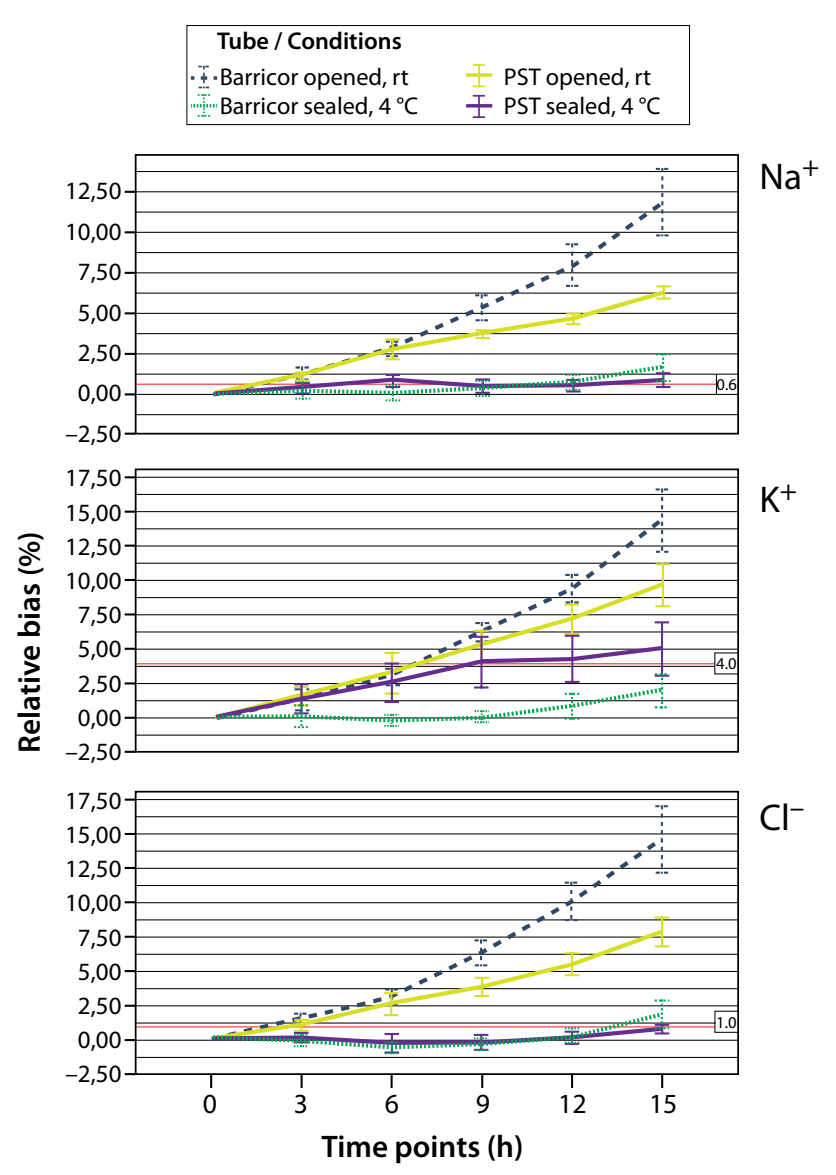

Figure 1. Stability curves in different groups. rt - room temperature.

For sealed refrigerated tubes, we observed a slight increase through time in $\mathrm{Na}^{+}$, statistically significant at many time points but only clinically signifi-

TABLE 1. Group characteristics and basal electrolyte concentrations

\begin{tabular}{|c|c|c|c|c|}
\hline & Barricor Open, rt & $\begin{array}{c}\text { Barricor } \\
\text { Sealed, } 4^{\circ} \mathrm{C} \\
\end{array}$ & $\begin{array}{c}\text { PST II } \\
\text { Open, rt }\end{array}$ & $\begin{array}{c}\text { PST II } \\
\text { Sealed, } 4^{\circ} \mathrm{C}\end{array}$ \\
\hline Volunteers (N) & 10 & 10 & 11 & 11 \\
\hline Tubes included for analysis (N) & 10 & 8 & 11 & 10 \\
\hline Basal Na+(mmol/L) & $140.7(1.8)$ & $141.2(2.0)$ & $139.3(4.4)$ & $138.6(3.4)$ \\
\hline Basal K+ (mmol/L) & $4.1(0.5)$ & $4.1(0.2)$ & $4.3(0.7)$ & $4.0(0.5)$ \\
\hline Basal Cl- (mmol/L) & $105.2(2.5)$ & $107.4(4.8)$ & $103.9(4.9)$ & $106.2(4.1)$ \\
\hline $\mathrm{Na}+\mathrm{CVa}(\%)$ & 0.22 & 0.21 & 0.20 & 0.18 \\
\hline $\mathrm{K}^{+} \mathrm{CVa}(\%)$ & 0.13 & 0.20 & 0.21 & 0.22 \\
\hline $\mathrm{Cl}^{-} \mathrm{CVa}(\%)$ & 0.30 & 0.25 & 0.18 & 0.21 \\
\hline
\end{tabular}

$\mathrm{rt}$ - room temperature. Basal concentrations of $\mathrm{Na}^{+}, \mathrm{K}^{+}$and $\mathrm{Cl}^{-}$are presented as mean (standard deviation). $\mathrm{CVa}-$ average of analytical coefficients of variation between pairs of repetitions. 
TABLE 2. Relative bias with respect to basal concentrations

\begin{tabular}{|c|c|c|c|c|c|c|}
\hline \multirow[b]{2}{*}{ GROUP } & & \multicolumn{5}{|c|}{ Relative bias (\%) and P } \\
\hline & & $3 \mathrm{~h}$ & $6 \mathrm{~h}$ & $9 \mathrm{~h}$ & $12 \mathrm{~h}$ & $15 \mathrm{~h}$ \\
\hline \multirow{4}{*}{$\begin{array}{l}\mathrm{Na}^{+} \\
(\mathrm{MAB}= \\
0.6 \%)\end{array}$} & PST II open, rt & $\begin{array}{c}1.13(0.87-1.38)^{*} \\
P<0.001\end{array}$ & $\begin{array}{c}2.77(2.14-3.39)^{*} \\
P<0.001\end{array}$ & $\begin{array}{c}3.71(3.48-3.94)^{*} \\
P<0.001\end{array}$ & $\begin{array}{c}4.64(4.34-4.94)^{*} \\
P<0.001\end{array}$ & $\begin{array}{c}6.28(5.92-6.65)^{*} \\
P<0.001\end{array}$ \\
\hline & $\begin{array}{l}\text { PST II sealed, } \\
4^{\circ} \mathrm{C}\end{array}$ & $\begin{array}{c}0.39(0.13-0.65)^{\dagger} \\
P=0.007\end{array}$ & $\begin{array}{c}0.81(0.46-1.16)^{\dagger} \\
P<0.001\end{array}$ & $\begin{array}{c}0.48(0.08-0.88)^{\dagger} \\
P=0.026\end{array}$ & $\begin{array}{c}0.50(0.16-0.83)^{\dagger} \\
P=0.008\end{array}$ & $\begin{array}{c}0.85(0.41-1.29)^{\dagger} \\
P=0.002\end{array}$ \\
\hline & $\begin{array}{l}\text { Barricor open, } \\
\text { rt }\end{array}$ & $\begin{array}{c}1.26(0.85-1.67)^{*} \\
P<0.001\end{array}$ & $\begin{array}{c}2.82(2.43-3.22) \\
P<0.001\end{array}$ & $\begin{array}{c}5.33(4.59-6.07)^{*} \\
P<0.001\end{array}$ & $\begin{array}{c}7.95(6.62-9.27)^{*} \\
P<0.001\end{array}$ & $\begin{array}{c}11.82(9.82-13.81)^{*} \\
P<0.001\end{array}$ \\
\hline & $\begin{array}{l}\text { Barricor sealed, } \\
4{ }^{\circ} \mathrm{C}\end{array}$ & $\begin{array}{c}0.20(-0.31-0.71) \\
P=0.387\end{array}$ & $\begin{array}{c}0.10(-0.38-0.57) \\
P=0.655\end{array}$ & $\begin{array}{c}0.32(-0.09-0.73) \\
P=0.112\end{array}$ & $\begin{array}{c}0.73(0.29-1.18)^{\dagger} \\
P=0.006\end{array}$ & $\begin{array}{c}1.64(0.80-2.48)^{*} \\
P=0.002\end{array}$ \\
\hline \multirow{4}{*}{$\begin{array}{l}\mathrm{K}^{+} \\
\text {(MAB = } \\
4 \%)\end{array}$} & PST II open, rt & $\begin{array}{c}1.68(1.10-2.26)^{\dagger} \\
P<0.001\end{array}$ & $\begin{array}{c}3.31(1.81-4.80)^{\dagger} \\
P<0.001\end{array}$ & $\begin{array}{c}5.31(4.17-6.44)^{*} \\
P<0.001\end{array}$ & $\begin{array}{c}7.19(6.11-8.27)^{*} \\
P<0.001\end{array}$ & $\begin{array}{c}9.72(8.16-11.28)^{*}, \\
P<0.001\end{array}$ \\
\hline & $\begin{array}{l}\text { PST II sealed, } \\
4^{\circ} \mathrm{C}\end{array}$ & $\begin{array}{c}1.43(0.41-2.44)^{\dagger} \\
P=0.007\end{array}$ & $\begin{array}{c}2.62(1.24-4.00)^{\dagger} \\
P=0.002\end{array}$ & $\begin{array}{c}4.09(2.24-5.94)^{\dagger} \\
P<0.001\end{array}$ & $\begin{array}{c}4.36(2.70-6.02)^{\dagger} \\
P<0.001\end{array}$ & $\begin{array}{c}5.09(3.10-7.09)^{\dagger} \\
P<0.001\end{array}$ \\
\hline & $\begin{array}{l}\text { Barricor open, } \\
\mathrm{rt}\end{array}$ & $\begin{array}{c}1.38(0.60-2.17)^{\dagger} \\
P=0.003\end{array}$ & $\begin{array}{c}3.20(2.39-4.00)^{\dagger} \\
P<0.001\end{array}$ & $\begin{array}{c}6.30(5.60-7.01)^{*} \\
P<0.001\end{array}$ & $\begin{array}{c}9.42(8.37-10.47)^{*} \\
P<0.001\end{array}$ & $\begin{array}{c}14.46(12.2-16.7)^{*} \\
P<0.001\end{array}$ \\
\hline & $\begin{array}{l}\text { Barricor sealed, } \\
4{ }^{\circ} \mathrm{C}\end{array}$ & $\begin{array}{c}0.14(-0.66-0.94) \\
P=0.685\end{array}$ & $\begin{array}{c}-0.15(-0.49-0.20) \\
P=0.351\end{array}$ & $\begin{array}{c}0.14(-0.19-0.48) \\
P=0.351\end{array}$ & $\begin{array}{c}0.89(0.02-1.76)^{\dagger} \\
P=0.048\end{array}$ & $\begin{array}{c}2.00(0.77-3.22)^{\dagger} \\
P=0.006\end{array}$ \\
\hline \multirow{4}{*}{$\begin{array}{l}\mathrm{Cl}^{-} \\
(\mathrm{MAB}= \\
1 \%)\end{array}$} & PST II open, rt & $\begin{array}{c}1.06(0.67-1.45)^{\dagger} \\
P<0.001\end{array}$ & $\begin{array}{c}2.6(1.8-3.41)^{*} \\
P<0.001\end{array}$ & $\begin{array}{c}3.87(3.20-4.54)^{*} \\
P<0.001\end{array}$ & $\begin{array}{c}5.50(4.73-6.26)^{*} \\
P<0.001\end{array}$ & $\begin{array}{c}7.86(6.80-8.92)^{*} \\
P<0.001\end{array}$ \\
\hline & $\begin{array}{l}\text { PST II sealed, } \\
4^{\circ} \mathrm{C}\end{array}$ & $\begin{array}{c}0.19(-0.09-0.47) \\
P=0.168\end{array}$ & $\begin{array}{c}-0.23(-0.88-0.41) \\
P=0.440\end{array}$ & $\begin{array}{c}-0.20(-0.71-0.32) \\
P=0.423\end{array}$ & $\begin{array}{c}0.13(-0.32-0.58) \\
P=0.496\end{array}$ & $\begin{array}{c}0.8(0.53-1.06)^{\dagger} \\
P<0.001\end{array}$ \\
\hline & $\begin{array}{l}\text { Barricor open, } \\
\mathrm{rt}\end{array}$ & $\begin{array}{c}1.57(1.14-2.01)^{*} \\
P<0.001\end{array}$ & $\begin{array}{c}3.14(2.64-3.65)^{*} \\
P<0.001\end{array}$ & $\begin{array}{c}6.43(5.55-7.30)^{*} \\
P<0.001\end{array}$ & $\begin{array}{c}9.99(8.64-11.35)^{*} \\
P<0.001\end{array}$ & $\begin{array}{c}14.63(12.2-17.04)^{*}, \\
P<0.001\end{array}$ \\
\hline & $\begin{array}{l}\text { Barricor sealed, } \\
4^{\circ} \mathrm{C}\end{array}$ & $\begin{array}{c}0.11(-0.51-0.29) \\
P=0.517\end{array}$ & $\begin{array}{c}-0.52(-0.91-0.13)^{\dagger} \\
P=0.015\end{array}$ & $\begin{array}{c}-0.34(-0.73-0.06) \\
P=0.080\end{array}$ & $\begin{array}{c}0.24(-0.27-0.76) \\
P=0.316\end{array}$ & $\begin{array}{c}1.84(0.81-2.87)^{\dagger} \\
P=0.004\end{array}$ \\
\hline
\end{tabular}

Relative bias is presented as mean with $95 \%$ confidence intervals. $\mathrm{rt}$ - room temperature. MAB - maximum allowable bias. $3 \mathrm{~h}, 6 \mathrm{~h}$, $9 \mathrm{~h}, 12 \mathrm{~h}, 15 \mathrm{~h}-3,6,9,12$ and 15 hours sample storage, respectivelly. $\mathrm{P}$ - value of paired two-tailed t-test between the time value and the basal value ( 0 hours). $P<0.05$ was considered statistically significant.

${ }^{*}$ Clinically significant (lower confidence interval outside MAB).

tStatistically, but not clinically significant.

cant in Barricor tubes after 12 hours. Instead, in $\mathrm{Cl}^{-}$ we observed a slight initial decrease, followed by a statistically significant increase after 12 hours, not reaching clinical significance. In $\mathrm{K}^{+}$we found a statistically significant increase after 3 hours in PST II tubes, with a lineal increase of approximately $0.4 \%$ per hour. However, in Barricor tubes no significant change was observed until 9 hours, when a statistically significant increase appeared. In neither tube, clinical significance (4\%) was reached.

\section{Discussion}

When applying, biological variation based specifications (6), we found that open tubes kept at room temperature showed significant losses of stability for electrolytes due to evaporation. Concentrations increased over time being clinically significant at 3 hours for $\mathrm{Na}^{+}$, and $\mathrm{Cl}^{-}$and at 9 hours for $\mathrm{K}+$; this should be noted since these turnaround times are not unusual in many automated routine laboratories. In these laboratories, samples could wait uncapped for hours before finishing all their 
determinations and additional tests could be requested on these samples.

A recent study with open serum samples kept at room temperature for 16 hours found an 8.7 $\mathrm{mmol} / \mathrm{L}$ mean variation for $\mathrm{Na}+, 0.24 \mathrm{mmol} / \mathrm{L}$ for $\mathrm{K}^{+}$and $6.8 \mathrm{mmol} / \mathrm{L}_{\text {for }} \mathrm{Cl}^{-}$(1). Nauck et al. found serum $\mathrm{Na}^{+}$concentration increased about $13 \%$ in 0.5 $\mathrm{mL}$ samples and $3 \%$ in $2 \mathrm{~mL}$ samples kept opened at $22{ }^{\circ} \mathrm{C}$ for 24 hours; the evaporation rate was smaller (5\%) for $0.5 \mathrm{~mL}$ samples kept opened and refrigerated for 1 day (7). Our results are in agreement with these, although with slightly higher evaporation in our environment.

Previous studies also corroborate our findings that $\mathrm{Na}^{+}$and $\mathrm{Cl}^{-}$are clinically stable up to more than 15 hours in capped and refrigerated plasma and serum samples $(3,8)$.

$\mathrm{K}^{+}$, a predominantly intracellular ion, is known to be very susceptible to interference from blood cells. Some authors observed variations of $13.8 \%$ after only 4 hours in capped whole blood samples kept at $4{ }^{\circ} \mathrm{C}$ (3). In our sealed-refrigerated group, the PST II tube showed significant $\mathrm{K}^{+}$increase after 3 hours compared to Barricor tube, which remains statistically stable up to 12 hours. Our results are similar to those previously described: $+0.8 \%$ after 2 hours and $+1.4 \%$ after 4 hours at $4{ }^{\circ} \mathrm{C}$ in plasma samples (3). However, we did not find clinically significant loss of stability (4\%) in any tube up to 15 hours. Likewise, Brandhorst found the limit of + $5.6 \%$ for $\mathrm{K}^{+}$was reached, according to a generalized model, after $10-13$ hours at $4{ }^{\circ} \mathrm{C}$ in plasma tubes from four different manufacturers (8).

These outcomes are in agreement with manufacturer's findings that $\mathrm{K}^{+}$is slightly more stable in sealed Barricor tubes than in serum SST II tubes, both of them improving stability compared to PST II tubes (5). This could be explained by the improved plasma purification in Barricor tubes or in serum tubes; whereas in PST II tubes cells and platelets might be entrapped in plasma during the fast gel migration and barrier formation. In cellfree serum or plasma $\mathrm{K}^{+}$can be stable at ambient temperature for at least 56 hours $(4,8)$.
Our study has some limitations. Repeated analysis on the same sample might decrease sample volume, which has been associated to greater sample evaporation (2); however, based on the Siemens Vista documentation, this volume should not exceed $600 \mu \mathrm{L}$ after the 15 hours (9). We cannot exclude some degree of evaporation in sealed tubes since those were opened during analysis (approximately 5 minutes at each time point), even though we re-sealed them as soon as possible. This could explain the slight increase in $\mathrm{Na}^{+}$and $\mathrm{Cl}^{-}$in those tubes; we expected to find a decrease in these analytes due to influx into erythrocytes in the context of $\mathrm{Na}^{+} / \mathrm{K}^{+}$ATPase failure. In addition, initial volumes in tubes were slightly different (3.5 vs. 5 $\mathrm{mL}$ ) between both types of tubes.

Additionally, since we applied the "safest criteria" (only considering clinically significant when the $\mathrm{Cl}$ is greater than the specification) we might have overestimated stability times. Similar studies including more samples could find slightly inferior ones.

To conclude, evaporation is an important factor in electrolytes stability. In open tubes kept at room temperature we found clinically significant loss of stability at three hours for some analytes $\left(\mathrm{Na}^{+}\right.$and $\left.\mathrm{Cl}^{-}\right)$.

On usual storage conditions, sealed and refrigerated tubes did not show any clinically significant loss of stability in electrolytes up to 12 hours in Barricor tubes and up to 15 hours in PST tubes. We observed a progressive increase in $\mathrm{K}^{+}$that was more pronounced in PST II tube, maybe related to the presence of more residual blood cells in this type of tube when compared to Barricor tubes.

\section{Acknowledgements}

The authors want to express their gratitude to Becton Dickinson for providing the tubes used in this study.

\section{Potential conflict of interest}

None declared. 


\section{References}

1 Kift RL, Byrne C, Liversidge R, Babbington F, Knox C, Binns J, et al. The effect of storage conditions on sample stability in the routine clinical laboratory. Ann Clin Biochem 2015;52:6759. https://doi.org/10.1177/0004563215580000.

2. Burtis CA. Sample evaporation and its impact on the operating performance of an automated selective-access analytical system. Clin Chem 1990;36:544-6.

3. Oddoze C, Lombard E, Portugal H. Stability study of 81 analytes in human whole blood, in serum and in plasma. Clin Biochem 2012;45:464-9. https://doi.org/10.1016/j.clinbiochem.2012.01.012.

4. Boyanton BL, Blick KE. Stability studies of twentyfour analytes in human plasma and serum. Clin Chem 2002;48:2242-7.

5. Becton Dickinson. Within-Tube Stability of Selected Routine Chemistry Analytes and Immunoassays in BD Vacutainer ${ }^{\circledR}$ Barricor $^{\mathrm{TM}}$ Tubes in Comparison with BD Vacutainer ${ }^{\circledast}$ PST $^{\mathrm{TM}}$ II and SST ${ }^{\mathrm{TM}}$ II Advance Tubes at Multiple Time Points Post Centrifugation. BD White Paper VS9295-OUS-WP. NJ, USA. 2016.
6. Alsina MJ, González-Oller RK, SEQC Comité de Garantía de la Calidad y acreditación de Laboratorios. Definición del límite de estabilidad de las magnitudes en las muestras biológicas. Química Clínica 2006;25:81-5. (in Spanish).

7. Nauck $M$, Nauck $M$, Koetting J. A recapping system for automatic, semiautomatic, and manual use. Arch Pathol Lab Med 2008;132:690-3.

8. Brandhorst G, Engelmayer J, Götze S, Oellerich M, von Ahsen N. Pre-analytical effects of different lithium heparin plasma separation tubes in the routine clinical chemistry laboratory. Clin Chem Lab Med 2011;49:1473-7. https://doi. org/10.1515/CCLM.2011.606.

9. Siemens Healthineers. Dimension Vista. Guía de Ayuda. Manual Avanzado Clientes Vista. V: 02_01_2012. Erlangen, Germany. 2012. 